\title{
Hunger by Choice? Rethinking Food Security Strategies
}

\author{
Shadreck Tanyanyiwa
}

\begin{abstract}
Food insecurity is a global threat with devastating effects, particularly in 'developing' countries. This threat is worsened by a parochial perspective in most of southern Africa that associates food security with the major staple crop maize. This bias is witnessed in the amount of land, investments, research, and marketing allocated to maize, in comparison to traditional crops such as millet, rapoko and sorghum. However, increased investments in agriculture, particularly maize production has failed to translate to increased production of the crop, particularly in Zimbabwe. The vagaries of climate-change manifested through droughts, coupled with man-made policy disasters are evidence enough to factor diversified production systems to include traditional crops into the food security basket.

Since independence in 1980, Zimbabwe has experienced more than a dozen drought periods, which translates into multimillion dollar food imports. To feed the growing number of food insecure people, the solution could be in the shunned small grains, whose resilience in harsh conditions compared to maize, calls for urgent transformation and orchestration of the food security basket. Through renewed focus on traditional crops, Zimbabwe and other countries in east and southern African could attain food secure status and ensure that food as a human right is available to all.
\end{abstract}

Index Terms - Drought, food security, irrigation, traditional crops, small grains, sustainability.

\section{INTRODUCTION}

Since 2014, the number of people affected by hunger has been increasing. About $8.9 \%$ of the world's population 690 million people go to bed on an empty stomach each night. The number is expected to exceed 840 million by 2030 , the year that the world is expected to celebrate zero hunger. However, because of a host of man-made problems, celebrating zero hunger remains a pipe dream, even though there is plenty of food around to feed millions of hungry mouths in the world. Global food insecurity has been compounded by COVID-19 pandemic that threatens to reverse decades of progress in the fight against global poverty. The World Bank estimated that COVID-19 could have placed 88 million to 115 million people into extreme poverty in 2020 , with the total rising to as many as 150 million by the end of 2021 .

Food security world over, is under extreme threats due to factors that are largely man-made. Most of Africa relies on food imports, because of failed policies of governments and donors that have created a dependency syndrome that drains billions of dollars every year [1]. Money, which could be used to develop irrigation infrastructure, research, and procure small grain inputs to empower rural communities.
There are three areas that I think, if addressed could develop food secure communities, who would not only be food self-sufficient, but could trade surplus crops and diversify their household livelihood portfolios. First, there is urgent need for new vigor towards diversifying food production systems. In southern Africa food security is associated with maize, which is failing to cope with the vagaries of climate change induced droughts. Until about 1920s, drought resistant small grains millet, rapoko and sorghum were dominant crops in most of east and southern Africa. These small grains are not only resilient against harsh weather conditions, but of great nutritional value.

Second, one of the biggest contributors to food insecurity is drought. In mid-2017 four countries in the southern African region Lesotho, Malawi, Swaziland, and Zimbabwe declared national drought disasters. Experts predict that by $2030 \mathrm{crop}$ production in southern Africa and south Asia, would be severely affected by climate change. With ever increasing drought periods and inadequate rains because of climate change, countries are faced with perennial food shortages. The African Bank predicts that Africa's food imports would triple to USD110 billion by 2025 [2]. While the United Nations says that Africa may produce only $13 \%$ of her food needs [3]. Because climate change is now a reality, long dry spells should be an awakening call to invest more in irrigation infrastructure. Every year, millions of cubic litres of rainwater freely flows to waste, instead of being harvested for irrigation purposes. Money that goes into imports of grain, could be invested into small to medium sized dams for irrigation or weirs. Availability of water, and inputs would ensure food secure communities.

Third, armed conflicts caused by horizontal inequalities are also sources of food insecurity. Conflicts create food insecure communities through relocations as people flee internal armed war. Rural communities who host small-scale farmers bear the brunt of internal armed conflicts, as they abandon fertile soils to seek shelter in tents or foreign countries as refugees. In December 2020, there were reports that 110 rice farmers were killed in northeastern Nigeria by armed groups. While, in northern Mozambique, tens of thousands of people were forced to flee their homes and livelihoods because of armed conflict.

These man-made threats have created food insecure communities, whose vulnerability is a manifestation of inappropriate and failed policies whose consequence is chronic poverty. I believe these three areas are closely intertwined, without water there would be no food; if there is water and agricultural inputs in a politically unstable country, there would still be no food. Therefore, food security requires agricultural inputs, water and stability, even innovative ways 
of crop production can only be effective in stable environments. Hence, my belief that most countries, particularly in sub-Saharan Africa experience hunger by choice, explicitly manifested through bad governance. However, this paper focuses on diversifying the food security basket.

The Food and Agriculture Organisation FAO [4] defines food security as when all people, at all times, have physical, social and economic access to sufficient, safe and nutritious food that meets their dietary needs and food preferences for an active and healthy life. Food security affects more than human health and welfare, it also contributes to economic and political stability. Most countries that experience political instability are always associated with food insecure territories. Food insecurity in such countries might have been as a result of political instability or the political instability was as a result of food insecurity. One often led to the other but hey go hand in hand in the affected areas. Food insecurity exists when people lack sustainable physical or economic access to enough, safe, nutritious, and socially acceptable food for a healthy and productive life. Food insecurity may be chronic, seasonal, or temporary.

\section{RETHINKING FOOD SECURITY BASKET}

Zimbabwe is one country prone to erratic rainfall, droughts, and floods. Since independence in 1980, the southern African country has experienced about a dozen droughts ranging in magnitude from mild, severe to extreme ones that always compromise food security of the country. Even in years when the rains have been good, the agricultural season has often been weakened by mid-season dry spells or invasion of locusts. One of the worst drought periods was in 1991-1992, when the country had only 13, 000 tonnes of maize left, which translated to two days of food. A million cattle died. And people survived on imported yellow maize, normally produced as stock feed in the exporting countries.

In Zimbabwe, food security is mainly associated with maize for staple food and wheat. Small grains, such as sorghum, rapoko (finger millet) and mhunga (pearl millet), play an insignificant role in household food security. Food preferences tend to limit crop diversification of the food security basket. Even in the drier areas of the Mid-Zambezi valley such as Mushumbi, Kanyemba and Muzarabani where small grains could be produced economically and sustainably, maize is the backbone of household food security. This despite that sorghum productivity in the MidZambezi valley averages $0.9 \mathrm{MT} / \mathrm{ha}$, which is higher than the national average of $0.5 \mathrm{MT} / \mathrm{ha}$, [5]. However, the acreage for small grains in areas with potential is smaller compared to maize. The small grains are mostly grown as back-up crops at subsistence level, save for a few commercial and smallscale farmers contracted by breweries. One of the small grains, sorghum is more nutritious than maize and richer in carbohydrates, vitamins, and minerals. It contains dietary fibre, with higher protein, calcium, and iron content.

The rationale for a shift from maize production to small grain production is premised on a number of scientific reasons. Sorghum and millet are believed to be more ecologically compatible with semi-arid areas compared to maize because of their drought tolerance [6], [4]. It is on the basis of their strong adaptive advantage to climate change and lower risk of failure in comparison to maize that they are advocated for. The FAO and International Crops Research Institute for the Semi-Arid Tropics (ICRISAT) [7] argues that sorghum and millet have the potential to contribute towards food security in many of the world's poorest and most food insecure agro-ecological zones like Zimbabwe. It has been argued that sorghum and millet have the potential to improve household food security in semi-arid regions because of their adaptability to such environments [8]. Small grains require little input during growth and with increasing world populations and decreasing water supplies, they will be important crops for future human use [9]. Some of the small grains such as finger millet grows in a wide range of climatic conditions. The crop has a long storage life and is seldom attacked by insects and molds. The long storage life of small grains makes them important as a risk avoidance strategy in food security [9]. Sorghum and millet have high levels of adaptation to African conditions; hence they constitute half the total of cereal production on the continent and as such could be a major source of protein for the population if grown at a large scale [8].

However, despite these positive attributes of small grains within the context of climate change, households in Zimbabwe, and the government continue to prioritise the production of maize, with miniscule promotion of small grains coming as an after-thought, especially, during periods of drought-induced food shortages. The decline in the production of small grains may also be attributed to the low incentives to farmers who grow the crop. Improving productivity of small grains is, therefore, the key to food and nutrition security in the context of climate change and variability [10]-[12].

\section{A. Government Support}

The Zimbabwe government has different maize input schemes aimed at boosting production of the staple crop. Nonetheless, [13] observes that not much benefit has been achieved from the government-subsidized input scheme, especially in the semi-arid regions. A report by the World Bank [14] echoed the same sentiments, saying that more public spending in agriculture by the Zimbabwe government has not translated into more productivity. The report also warned that without Climate-Smart Agriculture Investments, Zimbabwe's staple food crop, maize, is expected to see a $33 \%$ yield reduction by 2030 . The World Bank report provides the needed impetus for renewed vigor not only in promoting growing of small grains, but increasing the acreage of the small grains, research and marketing. However, according to FAO [15], the Zimbabwe government support measures for small grains have traditionally been relatively minimal, compared to maize. Even the gusto that accompanies campaigns for maize production are absent for small grains. This lack of support for small grains on the ground is a major obstacle to the development and growth of traditional crops. Similar findings by [16] show that lack of government support in Zimbabwe for production, processing and use of crops that are tolerant to drought has resulted in people in the drier areas changing their tastes from millet and sorghum to maize. Studies on the small grains conducted in Tsholotsho [17] and the Mid-Zambezi Valley [18] decry general lack of 
support. While Tsholotsho and Mid-Zambezi Valley in Zimbabwe's south-west and northern regions respectively, have ideal conditions for small grain production, small-scale farmers in the areas still attempt and allocate more hectares to cash crops. This is despite scientific evidence showing that small grains have a comparative advantage in these semi-arid regions over maize [19]-[21], [5]. Therefore, what is needed is an ideal agricultural policy by the government that would increase provision of small grains inputs to farmers in arid regions and the acreage.

Until December 2020, there had been generally, a strong financial incentive for the production of maize rather than small grains, which was promoted partly by government policy and agricultural extension services with aggressive marketing by seed houses and millers, favorable pricing policies and good demand [21], [8]. Towards the end of 2020, the Zimbabwe government announced new pre-planting producer prices of crops, with small grains pegged at ZW \$38, 000.00 (about USD100.00 as per January 27 $7^{\text {th }}$ 2021, exchange rate), while maize was ZW\$32, 000.00 (about USD85.00 as per January $27^{\text {th }} 2021$ exchange rate). While the figures might be high, the unpredictability of the Zimbabwe currency that competes sharply with the US dollar, makes the numbers meaningless. High-yielding maize varieties and technology are also readily available in comparison to small grains where there is little attention in terms of breeding and genetic improvement of sorghum and millet crop varieties. However, this renewed impetus by the government to shore up production of small grains is not matched by action on the ground.

In most countries, there is a ready market for maize than small grains. Therefore, for sorghum and millet to compete with maize in the limited resources of the communal farmers, there is a need for the crops to outperform maize in terms of yields. This entails massive public-private investment in the development of hybrid sorghum and millet varieties with higher yields and better taste than previous varieties and maize.

\section{B. Why Low Uptake in Small Grain Production}

Subdued small grains advocacy is one of the major contributors to low uptake of the small grain production. Marketing of the small grains is not aggressive as that of maize. Besides, marketing campaigns, the small grains are labour intensive compared to maize. Increasing labour costs in small grain production have affected most farm operations, from land preparation, weeding, bird scaring to harvesting and grain processing [19], [10]. The high costs of producing small grains, is therefore, a major deterrent for small-scale farmers, who then resort to maize that is produced and processed with much ease. Coupled to labour costs, there is lack of improved varieties and credit, weeds, pests, and diseases that limits the adoption of small grains as a strategy for climate change adaptation [19], [10].

Even under semi-arid conditions, it might be difficult for small grains to compete with maize, because crops such as sorghum and millet do not yield much crop residue, which plays a very important role in smallholder farmers in terms of animal feed and crop manure. Similar observations were noted by [22] that livestock depends upon crop residues for survival during the winter, mainly from maize stalks. Small grains do not offer fodder for cattle, unlike maize which feeds both the farmers and their livestock. Consequently, smallholder farmers continually have an inclination towards maize production.

Small grains production is unattractive to smallholder farmers because the crops are much prone to consumption by quelea birds. Therefore, many people are reluctant to grow millet and rapoko in fear of huge flocks of voracious redbilled quelea birds that have the potential to wipe out crops resulting in low yields [24]. The red-billed quelea bird is a major threat of small grain crops in Zimbabwe both on irrigated wheat and barley in the winter and on sorghum and millet in the summer.

Farming of small grains like finger millet requires knowledge, especially during weeding time as it tends to have weeds that look exactly like the plant [25]. To the unpracticed eye, it is difficult to distinguish, and this may result in pulling out the finger millet leaving out the weed. Therefore, there is a need for more education among the rural households especially the young generation [25]. Furthermore, due to lack of knowledge, most farmers do not allocate more inputs to small grains compared to maize. Some grow small grains in the worst part of cropping land and others do not prioritize time of planting and fertilizer management [26]. This has a negative effect on production. Many assume that once the crop is planted, it grows up to harvesting without weed control.

\section{Quality of Yield}

In the low rainfall and high temperature areas of Southern Africa, agricultural production, processing, marketing and consumption systems are dominated by maize at the expense of potential 'orphan crops' such as sorghum [18]. Much research has produced different high yielding maize varieties that included short-season varieties, attempts have also been made on drought resistant varieties with limited success.

Increased calls to diversify food security basket, have not resonated with research into high yielding small grains varieties. Most small grain farmers still rely on low yielding varieties. Sorghum, one of the small grains is an important cereal crop in the Mid Zambezi Valley, with potential to be included in the main staple basket. Both subsistence and commercial cultivation is done in almost all parts of the region at different levels using varied resources. Sorghum production that averages $0.9 \mathrm{MT} / \mathrm{ha}$, in the region has potential to increase to $3.5 \mathrm{MT} / \mathrm{ha}$, if seed varieties are improved, inorganic fertilizer application enhanced, extensive use of extension services and input markets are developed. However, low yields of small grains are a hindrance and challenge for smallholder farmers who would want to adopt and expand production of traditional crops [18], [5]. This low productivity per hectare compared to maize, causes small grains to be unattractive to communal farmers in the semi-arid regions of Zimbabwe [27].

The small-scale farmers rely mostly on localized seed production initiatives, such as recycling seed from their storage. This has been attributed to weak institutional arrangements and structures that are rigid and marginalize sorghum [16]. For example, [16] reported that extension, research, and financial services frameworks used in Zimbabwe are ineffective and unresponsive to the demands 
of small-scale farmers in the arid areas where sorghum performs well. This coupled with infrastructural inadequacies that characterize small scale farming.

\section{Perception}

Sorghum is the third most important cereal crop in Zimbabwe and the principal food for many living in semi-arid rural regions. However, a number of households, especially, in urban areas do not like eating meals prepared using small grains such as rapoko, unless prescribed by medical doctors as part of organic or natural foods [17]. One reason is the colour (brown mealie meal or flour), taste and flavor and the general practices and lifestyles in some families. Furthermore, [2001] argues that in Gokwe area, millet has become unpopular with the new generation, which does not appreciate the advantages of traditional seed crops in resisting diseases and pests attack. Tsiko [28] also concurs pointing out that this causes reduced exploitation of traditional food, which may have a better nutritional value than commercial foods. There is also a social stigma associated with the consumption of traditional foods [28]. Small grains are viewed as poverty crops, mostly consumed by poor rural communities.

\section{E. Marketing}

The growth and sustainability of any crop production hinges on readily available markets that serves as a catalyst for farmers to produce more. However, for small grains there are limited formal marketing opportunities that are not as aggressive as the marketing for cash crops. Efforts made through contract farming to link farmers to niche markets such as brewing companies and some non-governmental organisations involved in seed distribution programs in Zimbabwe, have yielded insignificant results. There is, therefore, clearly lack of infrastructure to market the buying and processing of small grains, especially in dry areas, which discourages farmers from adopting these drought-resistant cereal varieties. Therefore, lack of market for the end products of the crops, discourages the farmers from producing small grains.

\section{CONCLUSION \& RECOMMENDATIONS}

The root cause of food insecurity in developing countries is the inability of people to gain access to food due to poverty. Effective policy formulation and implementation requires a degree of political willingness that translates policy into pragmatic action on the ground. Because each time disaster strikes maize production, there is a re-awakening of the dangers of over reliance on maize, resulting in piece-meal pledges to develop the potential of small grains. This culminates in temporary support for traditional small grains such as sorghum. However, in the post-drought period, the government support mechanisms evaporate, resulting in the re-domination of maize and dampening the prospects of further developing sorghum.

During drought periods the readily availability of maize from regional and international markets at relatively low prices, kills any interest to develop and market small grains. These markets that the government turns to whenever there is maize deficit, continuously push sorghum and other small grains into extinction. Studies have shown that there are limited value addition activities with sorghum, and this has compromised the crop's potential to generate sustainable margins for actors along multiple value chain nodes.

Sorghum remains important for sustainability of smallscale farmers' subsistence, social and economic livelihoods in semi-arid and arid communities of Southern Africa. There is, therefore, need for clear policy and incentives that promotes small grain crop production amongst smallholder farmers in Zimbabwe's semi-arid areas. Research should be done into more white varieties of small grains that can compete white maize mealie meal. Aggressive marketing of the small grain produces, and products should help change the eating habits and re-condition the taste buds of people especially, the millennium generation. Sorghum mealie meal could be introduced in school feeding schemes, so that children grow up being familiar with the taste of traditional crops.

In order to produce sufficient surplus of small grains, the government could compel beneficiaries of the land reform to set aside a fraction of their small, medium and large farms for small grains and avail extension services. New technologies to help curb destructive nature of quelea birds and control weed could help boost production. The government should take practical steps to teach smallholder farmers in Zimbabwe so that they know that it is strategic to grow and consume food that is suitable for their environments. Not only would this increase food security but would result in economic growth and development. Further, the government in partnership with the private sector should facilitate and encourage the development of the commodities market of small grains. This market would not only assist in price discovery of small grains, but it would create forward and backward linkages between food processors, financiers, investors, agro-dealers, speculators, and farmers to sustain the market of small grains. There would also be need for research and development of higher yielding and better tasting small grains varieties that are more acceptable to the market in order to enhance their uptake. However, what is certain is that people can grow and eat their own food only, if necessary, support is availed.

\section{REFERENCES}

[1] Grain, (July 2019). Food sovereignty is Africa's only solution to climate chaos. Available: https://www.grain.org/en/article/6293-foodsovereignty-is-africa-s-only-solution-to-climate-chaos.

[2] AfDB, (Africa Development Bank), (August 2016). Feed Africa: Strategic agricultural transformation in Africa 2016-2025. Available: https://www.afdb.org/fileadmin/uploads/afdb/Documents/PolicyDocuments/Feed_Africa-Strategy-En.pdf.

[3] Munang, R., Andrews, J., (December 2014). "Despite climate change, Africa can feed herself." Africa Renewal, 27 (4): 6-7. DOI: https://doi.org/10.18356/63bc5598-en.

[4] Food and Agricultural Organisation (FAO), 2008. An introduction to the basic concepts of food security. Available: http://www.fao.org/3/al936e/al936e.pdf.

[5] Mukarumbwa, P., Mushunje, A., (September 2010). "Potential of sorghum and finger millet to enhance household food security in Zimbabwe's semi-arid regions", presented at the Joint 3rd African Association of Agricultural Economists (AAAE) and 48th Agricultural Economists Association of South Africa (AEASA) Conference, Cape Town, South Africa, September 19-23.

[6] Dube, T., Mlilo, C., Moyo, P., Ncube, C., Phiri, K., (July 2018). Will adaptation carry the future? Questioning the long-term capacity of smallholder farmers' adaptation strategies against climate change in 
Gwanda District, Zimbabwe. Journal of Human Ecology, 61 (1-3), 2030 .

[7] Food and Agriculture Organisation (FAO), International Crops Research Institute for the Semi-Arid Tropics (ICRISAT), (June 2008). Special report on crop and food supply assessment mission to Zimbabwe 18 June $2008 . \quad$ Available: www.fao.org/docrep/010/ai49e/ai49e00.htm.

[8] Taylor, J. R., 2003. Overview importance of sorghum in Africa. Available: http://www.sciencedirect.com/science.

[9] Chazovachii, B., Chigwenya, A., Mushuku, A., (2012). Adoption of climate change resilient rural livelihoods through growing of small grains in Munyaradzi communal area, Gutu District. In African Journal of Agricultural Research, 7(8), 1335-1345. doi:10.5897/AJAR10.921.

[10] Matthew, S., (2015). The feasibility of small grains as anadoptive strategy to climate change. Russian Journal of Agricultural and SocioEconomic Sciences, 4(15), 40-55. DOI: 10.18551/rjoas.2015-05.04.

[11] Ndlovu, S., Mpofu, M., Moyo, P., (2019). Debunking the effectiveness of in-kind transfers in alleviating urban household food insecurity in Bulawayo, Zimbabwe. Development Southern Africa, 1-15. doi:10.1080/0376835X.2019.158403.

[12] Nhemachena, C., Mano, R., Mudombi, S., Muwanigwa, V., (2014). Climate change adaptation for rural communities dependent on agriculture and tourism in marginal farming areas of the Hwange District, Zimbabwe. African Journal of Agricultural Research, 9 (26), 2045-2054. doi:10.5897/AJAR2013.6779.

[13] Foti, R., Muringai, V., Mavunganidze, Z., (2007). Seed aid for food security? Some lessons from Zimbabwe's agricultural recovery programme. Bindura: Bindura University of Science and Education.

[14] World Bank, (2020). Climate-smart agriculture investments required to boost agricultural production in Zimbabwe. Available: https://www.worldbank.org/en/news/feature/2020/12/21/climatesmart-agriculture-investments-required-to-boost-agriculturalproduction-in-zimbabwe.

[15] Food and Agriculture Organisation (FAO), (2015). Conservation agriculture contributes to Zimbabwe economic recovery.

[16] Available: www.fao.org/inaction/conservation-agriculturecontributes-tozimbabwe-economic-recovery/en/.

[17] Rukuni, M., Tawonezvi, P., Eicher, C., Munyuki-Hungwe, M. Matondi, P., (2006). Zimbabwe's agricultural revolution revisited. Harare: University of Zimbabwe Publications

[18] Phiri, K., Dube, T., Moyo, P., Ncube C., Ndlovu, S., (2019). Small grains "resistance"? Making sense of Zimbabwean smallholder farmers' cropping choices and patterns within a climate change context. Cogent Social Sciences, 5. Available: https://doi.org/10.1080/23311886.2019.1622485.

[19] Musara, J.P., Musemwa, L., Mushunje, A., Mutenje, M., Pfukwa, C., (2019). Sorghum value chain analysis in semi-arid Zimbabwe. 47 (1) 164-178. Available: https://dx.doi.org/10.17159/24133221/2019/v47n1a497.

[20] Alumira, J., Rusike, J., (2005). The green revolution in Zimbabwe. Journal of Agricultural and Development Economics, 2(1), 50-66.

[21] Brazier, A. (2015). Climate change in Zimbabwe, facts for planners and decision makers. Harare: Konrad Adenauer Stiftung.

[22] Carney, D., Ashley, C., 1999. The sustainable livelihood approach to poverty reduction. Canada: SIDA.

[23] Muchineripi, C., (2014). Grain revolution; Finger millet and livelihood transformation in rural Zimbabwe. Harare: Africa Research Institute.

[24] Muchuru, S., Nhamo, G., (2019). A review of climate change adaptation measures in the African crop sector. Climate and Development, 1-13. doi:10.1080/7565529.2019.1585319.

[25] Wilhite, D. A., Hays, M. J., \& Knutson, C. L., (2005). Drought preparedness planning: Building institutional capacity. Journal of the American Resource Association.

[26] Dhliwayo, M., (2007). Human rights and climate change.

[27] Available:http://www.ciel.org/publications/Cimate/CaseStudy_Zimba bwe_Dec07.pdf doi: 10.1094/PDS-91-4-0467B.

[28] Gukurume, S., (2010). Farming and the food security-insecurity matrix in Zimbabwe: A case of ward 21 Chivi rural. Journal of Sustainable Development in Africa, 12(7), 40-52. ISSN: 1520-5509.

[29] Dube, C., (2008). The impact of Zimbabwe's drought policy on Sontala Rural community in Matabeleland South Province (MSc Thesis). Department of geology, Geography and environmental studies, Stellenbosch University. Available: https://scholar.sun.ac.za/bitstream/handle/10019.1/2138/dube_impact 2008.pdf.

[30] Sukume, C., Makudze, E., Mabeza-Chimedza, R., Zitsanza, N., (2000) Comparative economic advantage of crop production in Zimbabwe (Technical Paper No.99). Harare: Department of Agricultural Economics and Extension. University of Zimbabwe.
[31] Chisvo, M., 2001. Impact of liberalisation policies on food security in Zimbabwe (Workshop Report). Harare: Research Department.

[32] Tsiko, S., (2007). Wild food plants of Africa project. Harare: Gibbs Magazine.

Dr Shadreck Tanyanyiwa, was born in 1966, in Bindura, Mashonaland Central Province, Zimbabwe. He holds a Doctorate degree in Development Studies from the University of South Africa; MA Africa Studies, the Free State University, Honours in Development Studies, Unisa and BA Communication Science, Unisa.

He was a part time lecturer at the Midlands State University, Harare Campus. Currently, he is a senior lecturer in Development Studies at the North West University, Mafikeng Campus.

Dr Tanyanyiwa's research interests include Political economy; Peace \& Development; Food security \& sustainable livelihoods; Governance and Development; Community participation; Rural Development. 